\title{
PENGARUH PERLAKUAN BIBIT TERHADAP PERKEMBANGAN PENYAKIT LAYU BAKTERI PADA JAHE (ZINGIBER OFFICINALE)
}

\author{
Titik Nur Aeny ${ }^{1}$, Feriansyah², dan Subli Mujim ${ }^{1}$
}

\begin{abstract}
Effect of seedling treatments on development of bacterial wilt disease of ginger (Zingiber officinale). This experiment was aimed to study the effect of seedling treatment with bactericide on incubation period and disease intensity of bacterial wilt caused by Ralstonia solanacearum on ginger (Zingiber officinale). The experiment was conducted from May to November 2001, and the treatments were set as factorial experiment in completely randomised design. The first factor was the level of bactericide concentrations and the second factor was the length of soaking periods. Each treatment consisted of five plants and was replicated three times. Data were analysed with ANOVA and the means were compared with Duncan test. The results of analysis of variance showed that the interaction of bactericide concentrations with soaking periods was not significantly affected the incubation period and the intensity of bacterial wilt disease of ginger. However, those two factors significantly $(\mathrm{P}<0.01)$ affected the incubation period and the intensity of ginger bacterial wilt disease. Separation of the means by Duncan test indicated that the higher the bactericide concentration, the longer the incubation period. On the other hand, the disease intensity was lowered by the higher concentration. The effect of bactericide concentration $4 \mathrm{~g} / \mathrm{l}$ was not significantly different from that of $6 \mathrm{~g} / \mathrm{l}$. The analysis of variance was also showed that the length of soaking period of ginger seedling in bactericide did not affect the incubation period nor the disease intensity.
\end{abstract}

Key words: seedling treatment, bacterial wilt, ginger

\section{PENDAHULUAN}

Jahe (Zingiber officinale) sebagai salah satu tanaman rempah dan obat, mempunyai prospek pasar yang cukup baik di dalam maupun di luar negeri. Namun, volume dan nilai ekspor jahe dari Indonesia masih sangat berfluktuasi, padahal kebutuhan dunia selalu meningkat dari tahun ke tahun (Winarno, 1997). Hal ini dapat dianggap sebagai peluang yang baik bagi produsen jahe di Indonesia untuk mengusahakan tanaman ini dengan lebih serius sehingga dapat meningkatkan pendapatan daerah dan bahkan negara.

Di Indonesia, Provinsi Lampung merupakan salah satu daerah sentra produksi jahe. Jahe dari daerah ini ini selain untuk memenuhi permintaan dalam negeri juga untuk diekspor. Pada umumnya jahe yang diekspor adalah jahe besar atau dikenal dengan sebutan jahe gajah, sedangkan jahe kecil atau jahe emprit banyak dimanfaatkan oleh industri jamu di dalam negeri karena rasanya yang lebih pedas. Oleh karena itu, jahe gajah dianggap mempunyai nilai ekonomi yang lebih tinggi dari pada jahe emprit sehingga mendorong para petani jahe untuk mengusahakan jahe besar dalam skala yang lebih luas supaya produksinya dapat diekspor.
Sejalan dengan meningkatnya minat petani untuk bertanam jahe, harus disadarkan pula bahwa masih banyak kendala yang harus dihadapi dalam usaha peningkatan produksi jahe, baik kuantitas maupun kualitasnya. Salah satu masalah utama ialah adanya serangan patogen layu bakteri, Pseudomonas solanacearum, yang sekarang dikenal dengan nama Ralstonia solanacearum (Yabuchi et al., 1995; Supriyadi, 2000). Bakteri ini sangat sulit dikendalikan karena mampu bertahan cukup lama di dalam tanah tanpa tanaman inang. Selain itu, bakteri tersebut juga mempunyai kisaran inang yang cukup luas (Supriyadi, 2000). Dikin, Kornida, dan Hermawan (1997) melaporkan bahwa isolat bakteri $P$. solanacearum yang berasal dari pisang di Lampung dapat menyerang tanaman pisang, heliconia, dan jahe. Apabila hal ini benar, maka dikhawatirkan jahe di Lampung akan terancam karena penyakit yang sama telah menjadi masalah serius pada pertanaman pisang di daerah ini. Dengan demikian, sumber isolat bakteri tersebut bukan hanya berasal dari tanaman jahe melainkan juga dari tanaman pisang.

Beberapa cara pengendalian penyakit layu bakteri sudah pernah diteliti tetapi belum ditemukan cara yang efektif untuk mencegah maupun menanggulangi penyakit tersebut. Perlakuan bibit sebagai salah satu cara pengendalian preventif untuk

\footnotetext{
${ }^{1}$ Dosen Jurusan Proteksi Tanaman, Fakultas Pertanian Universitas Lampung

${ }^{2}$ Alumnus Jurusan Proteksi Tanaman, Fakultas Pertanian Universitas Lampung
} 
beberapa penyakit tanaman sudah banyak diketahui. Oleh karena itu, penelitian ini bertujuan untuk mempelajari pengaruh perlakuan bibit dengan bakterisida, khususnya dengan cara perendaman, terhadap masa inkubasi bakteri dan intensitas penyakit layu yang disebabkan oleh $R$. solanacearum yang berasal dari tanaman jahe terserang bakteri layu.

\section{METODE PENELITIAN}

Percobaan ini berlangsung dari bulan Mei sampai dengan November 2001. Bahan-bahan yang diperlukan antara lain ialah inokulum bakteri $(R$. solanacearum) yang diisolasi dari tanaman jahe layu bakteri, bibit jahe gajah, streptomisin sulfat 20\% (Agrept $20 \mathrm{WP}$ ), dan alkohol 70 \%. Peralatan yang digunakan antara lain ialah alat-alat untuk perawatan tanaman, pisau, tabung erlenmeyer, gelas labu, alat suntik, kantung plastik hitam, label, dan alat-alat tulis.

Perlakuan dalam percobaan ini disusun dalam rancangan acak lengkap dalam faktorial. Faktor pertama adalah tingkat konsentrasi formulasi bakterisida yang terdiri atas 4 taraf yaitu tanpa bakterisida (K1), konsentrasi 2 g/l (K2), konsentrasi 4 g/l (K3), dan konsentrasi 6 g/l (K4). Faktor kedua adalah lama perendaman bibit dalam bakterisida yang terdiri atas 3 taraf yaitu 2 jam (J1), 5 jam (J2), dan 8 jam (J3). Semua perlakuan diulang sebanyak tiga kali, dan setiap satuan percobaan terdiri atas lima bibit jahe. Selanjutnya bibit yang telah diberi perlakuan ditanam dalam polibeg berisi tanah steril yang telah dicampur dengan inokulum bakteri. Infestasi bakteri ke dalam tanah steril dilakukan tiga hari sebelum bibit ditanam. Data yang diperoleh diolah dengan sidik ragam dan nilai tengah antar perlakuan dibandingkan dengan menggunakan uji Duncan (SAS-Institute, 1988). Semua pengujian dilakukan pada taraf nyata $5 \%$.

Pengamatan awal dilakukan setiap hari sampai munculnya gejala pertama untuk menghitung masa inkubasi bakteri. Selanjutnya, pengamatan terhadap perkembangan gejala dan intensitas penyakit layu dilakukan seminggu sekali selama dua bulan. Intensitas penyakit merupakan persentase jumlah tanaman yang terserang per satuan percobaan. Pada akhir pengamatan, tanaman yang mati atau bergejala dibongkar dan diamati adanya gejala busuk pada rimpangnya.

\section{HASIL DAN PEMBAHASAN}

Dari hasil analisis ragam diketahui bahwa interaksi antara konsentrasi bakterisida dengan lama perendaman bibit tidak berpengaruh nyata terhadap masa inkubasi bakteri sehingga analisis difokuskan pada pengaruh utama masing-masing faktor. Dari dua faktor yang diuji ternyata hanya konsentrasi bakterisida yang berpengaruh sangat nyata terhadap masa inkubasi bakteri $R$. solanacearum (nilai $\mathrm{F}=$ 50,90 dan nilai $P=0,0001$ ), sementara lama perendaman tidak berpengaruh terhadap masa inkubasi bakteri. Hasil uji nilai tengah dengan metode Duncan menunjukkan bahwa makin tinggi konsentrasi bakterisida yang digunakan, makin lama masa inkubasi bakteri (Tabel 1).

Tabel 1. Masa inkubasi bakteri $R$. solanacearum pada bibit jahe setelah perlakuan bibit

\begin{tabular}{lc}
\hline Perlakuan & Masa inkubasi (hari ) \\
\hline Konsentrasi: & \\
$0 \mathrm{~g} / \mathrm{l}$ & $13,8 \mathrm{c}$ \\
$2 \mathrm{~g} / \mathrm{l}$ & $35,3 \mathrm{~b}$ \\
$4 \mathrm{~g} / \mathrm{l}$ & $41,6 \mathrm{~b}$ \\
$6 \mathrm{~g} / \mathrm{l}$ & $49,3 \mathrm{a}$ \\
\hline Nilai F & $50,90^{* *}$ \\
\hline Nilai P & 0,0001 \\
\hline Lama perendaman: & \\
2 jam & $32,6 \mathrm{a}$ \\
5 jam & $35,3 \mathrm{a}$ \\
8 jam & $37,2 \mathrm{a}$ \\
\hline Nilai F & 1,54 \\
\hline Nilai P & 0,2341 \\
\hline
\end{tabular}

Keterangan:

Nilai tengah yang diikuti dengan huruf yang sama dalam satu kolom menyatakan tidak berbeda nyata pada uji jarak berganda Duncan $(\alpha=5 \%)$.

Pada kontrol, yaitu bibit yang tidak direndam dalam larutan bakterisida, masa inkubasi bakteri adalah paling pendek, yaitu 13,8 hari. Hal ini diduga berkaitan dengan banyaknya bakterisida streptomisin sulfat $20 \%$ yang terserap oleh rimpang jahe pada masing-masing taraf perlakuan. Rimpang yang menyerap kadar bakterisida lebih tinggi diduga terhindar dari serangan bakteri yang berasal dari tanah dibandingkan dengan rimpang yang hanya memperoleh kadar bakterisida lebih rendah.

Hasil pengaruh lama perendaman bibit dalam bakterisida pada percobaan ini ternyata berbeda 
dengan hasil penelitian Asman dan Hadad (1989) yang melaporkan bahwa perendaman bibit jahe selama 24 jam dapat mencegah serangan bakteri sampai umur 44 hari, tetapi tidak dijelaskan berapa lama masa inkubasi atau kapan kemunculan gejala layu yang pertama kali. Perbedaan hasil ini mungkin berkaitan dengan waktu perendaman yang kurang lama dan selang waktu lama perendaman yang kurang besar, sehingga pengaruhnya terhadap masa inkubasi menjadi tidak terlihat nyata. Namun demikian, dari nilai rerata masa inkubasi dapat dilihat adanya kecenderungan bahwa bertambahnya waktu perendaman yang digunakan dapat meningkatkan masa inkubasi patogen. Dengan demikian, apabila lama perendaman diperpanjang maka kemungkinan akan diperoleh hasil yang signifikan.

Dari hasil pengamatan juga diketahui bahwa perkembangan gejala layu pada bibit jahe yang diberi perlakuan bakterisida, sangat lambat pada tiga minggu pertama pengamatan. Oleh karena itu, intensitas penyakit dihitung mulai pada pengamatan empat minggu setelah inokulasi. Hasil analisis sidik ragam memperlihatkan bahwa faktor konsentrasi bakterisida berpengaruh sangat nyata terhadap intensitas penyakit mulai pada empat minggu setelah inokulsi (4 msi).
Dalam waktu pengamatan yang sama, semakin tinggi konsentrasi bakterisida yang digunakan untuk perendaman bibit, semakin rendah intensitas penyakit layu (Tabel 2). Dengan demikian, dapat dikatakan bahwa bakterisida streptomisin sulfat $20 \%$ yang digunakan untuk perendaman bibit jahe dapat terserap dengan baik ke dalam jaringan tanaman dan bekerja secara sistemik untuk melindungi bibit tersebut dari serangan bakteri penyebab layu yang berasal dari tanah. Perlakuan bibit ini nampaknya cukup efektif dalam menekan intensitas penyakit layu bakteri apabila dilakukan sebelum bibit terinfeksi oleh bakteri. Pada percobaan ini, infestasi bakteri $R$. solanacearum dilakukan pada tanah steril yang digunakan sebagai media tanam, bukan disuntikkan langsung pada bibit. Seperti yang telah dilaporkan oleh Aeny (1999), perlakuan bakterisida berpengaruh nyata terhadap penurunan intensitas penyakit apabila inokulum bakteri belum berada dalam jaringan tanaman atau pada inokulasi dengan penyiraman akar. Akan tetapi, pengaruh tersebut tidak nyata apabila inokulum bakteri sudah lebih dahulu berada dalam jaringan tanaman atau inokulasi dengan penyuntikan batang.

Tabel 2. Intensitas penyakit layu bakteri pada tanaman jahe setelah perlakuan bibit

\begin{tabular}{|c|c|c|c|c|}
\hline \multirow{2}{*}{ Perlakuan } & \multicolumn{4}{|c|}{ Intensitas penyakit layu bakteri (\%) pada - } \\
\hline & $4 \mathrm{msi}$ & $6 \mathrm{msi}$ & $8 \mathrm{msi}$ & $10 \mathrm{msi}$ \\
\hline \multicolumn{5}{|l|}{ Konsentrasi: } \\
\hline $0 \mathrm{~g} / \mathrm{l}$ & $46.66 \mathrm{a}$ & $66.67 \mathrm{a}$ & $75.56 \mathrm{a}$ & $100.00 \mathrm{a}$ \\
\hline $2 \mathrm{~g} / \mathrm{l}$ & $0.00 \mathrm{~b}$ & $20.00 \mathrm{~b}$ & $44.44 \quad b$ & $75.56 \mathrm{~b}$ \\
\hline $4 \mathrm{~g} / \mathrm{l}$ & $2.22 \mathrm{~b}$ & $4.44 \mathrm{c}$ & $28.89 \mathrm{c}$ & $55.56 \mathrm{c}$ \\
\hline $6 \mathrm{~g} / \mathrm{l}$ & $0.00 \mathrm{~b}$ & $4.44 \mathrm{C}$ & $22.22 \mathrm{c}$ & $44.44 \mathrm{c}$ \\
\hline Nilai F & $107.00 * *$ & $70.23 * *$ & $41.55 * *$ & $32.18 * *$ \\
\hline Nilai P & 0.0001 & 0.0001 & 0.0001 & 0.0001 \\
\hline \multicolumn{5}{|c|}{ Lama perendaman: } \\
\hline 2 jam & $15.00 \mathrm{a}$ & $25.00 \mathrm{a}$ & $45.00 \mathrm{a}$ & 68.33 a \\
\hline 5 jam & 13.33 a & $25.00 \mathrm{a}$ & $41.67 \mathrm{a}$ & 68.33 a \\
\hline 8 jam & $8.33 \mathrm{a}$ & $21.67 \mathrm{a}$ & $41.67 \mathrm{a}$ & $70.00 \mathrm{a}$ \\
\hline Nilai F & 3.25 & 0.40 & 0.36 & 0.07 \\
\hline Nilai P & 0.0564 & 0.6747 & 0.6989 & 0.9357 \\
\hline
\end{tabular}

Keterangan:

msi = minggu setelah inokulasi.

Nilai tengah yang diikuti dengan huruf yang sama dalam satu kolom menyatakan tidak berbeda nyata pada uji jarak berganda Duncan ( $\alpha=5 \%)$. 
Dilihat dari kemampuannya dalam menekan intensitas penyakit pada $8 \mathrm{msi}$ dan $10 \mathrm{msi}$, konsentrasi bakterisida $4 \mathrm{~g} / \mathrm{l}$ tidak berbeda nyata dengan konsentrasi $6 \mathrm{~g} / \mathrm{l}$. Oleh karena itu dapat dikatakan bahwa konsentrasi bakterisida streptomisin sulfat $4 \mathrm{~g} / \mathrm{l}$ sudah cukup efektif jika digunakan untuk perlakuan perendaman bibit jahe.

Seperti halnya pada peubah pengamatan masa inkubasi, faktor konsentrasi bakterisida juga berpengaruh sangat nyata terhadap peubah intensitas penyakit, sedangkan faktor lama perendaman bibit jahe tidak berpengaruh nyata. Diduga hasil ini juga masih berkaitan dengan dengan lama perndaman bibit jahe yang kurang lama, yaitu hanya $2-8$ jam. Kemungkinan, pengaruh lama perendaman akan lebih nyata dalam menekan intensitas penyakit apabila waktunya diperpanjang sampai 12 - 24 jam, seperti yang dilaporkan oleh Asman dan Hadad (1989) dan Hadiwiyono (1999). Hasil penelitian Hadiwiyono menunjukkan bahwa perendaman stek batang panili selama 12 jam dalam ekstrak bawang-bawangan (sebagai bakterisida nabati) dengan dosis tertentu mampu menekan intensitas penyakit busuk batang panili (Fusarium oxysporum f.sp. vanillae) di pembibitan panili.

\section{KESIMPULAN}

Dari hasil penelitian ini dapat disimpulkan bahwa (1) konsentrasi bakterisida untuk perendaman bibit jahe berpengaruh terhadap masa inkubasi bakteri $R$. soalanacearum, semakin tinggi konsentrasi semakin panjang masa inkubasi; (2) konsentrasi bakterisida 4 g/l cukup efektif dalam menekan intensitas penyakit sampai dengan 10 minggu setelah inokulasi; dan (3) lama perendaman bibit jahe maupun interaksinya dengan konsentrasi bakterisida tidak berpengaruh terhadap masa inkubasi maupun intensitas penyakit layu bakteri pada jahe.

\section{SANWACANA}

Pada kesempatan ini penulis mengucapkan terima kasih kepada Proyek Peningkatan Kualitas Sumber Daya Manusia Direktorat Pembinaan Penelitian dan Pengabdian pada Masyarakat Ditjen Dikti yang telah mendanai penelitian ini. Ucapan terima kasih juga penulis sampaikan kepada Ir. Efri,
M.S. dan Dr. Hasriadi Mat Akin, M.S. yang telah memberikan saran dan perbaikan untuk tulisan ini.

\section{DAFTAR PUSTAKA}

Aeny, T. N. 1999. Pengaruh Bakterisida dan Fungisida terhadap Intensitas Penyakit Layu Bakteri (Pseudomonas solanacearum) pada Pisang. J. Pen. Pengb. Wil. Lahan Kering, No. 22/23.

Asman, A., \& E.A. Hadad. 1989. Pemberian agrimisin, abu sekam, ekstrak bawang merah dan bawang putih pada tanah terkontaminasi Peudomonas solanacearum untuk pertanaman jahe. Bul. Litro. 4: 66-68.

Buddenhagen, I. W. 1986. Bacterial Wilt Revisited. In Bacterial Wilt in Asia and the South Pasific. Proceedings of an International Workshop held at PCARRD. Los Banos, Philippines. October 1985. G.J. Persley (Ed.) ACIAR Proceeding 13: 126-143.

Dikin, A., F. Kordina, dan Hermawan. 1997. Perbedaan Isolat Bakteri Penyebab Penyakit Layu Pisang di Lampung dan Jawa. Risalah Kongres Nasional XIII dan Seminar Ilmiah, Perhimpunan Fitopatologi Indonesia. Mataram, 25-27 September 1995. Hlm. 407410.

Hadiwiyono. 1999. Pengaruh Perlakuan Stek Batang dengan Ekstrak Bawang- bawangan terhadap Intensitas Busuk Batang Panili (Fusarium oxysporum f.sp. vanillae Schl.) di Pembibitan. Prosiding Kongres Nasional XV dan Seminar Ilmiah PFI. Purwokerto, 16 18 September 1999. Hlm. 561-568.

SAS Institute. 1988. User's Guide. SAS Institute Inc. Cary, NC, USA. 1028 pp.

Supriadi. 2000. Penyakit Layu Bakteri (Ralstonia solanacearum) pada Tumbuhan Obat dan Strategi Penanggulangannya. Jurnal Penelitian dan Pengembangan Pertanian 19(1): 17- 26. 
Yabuchi, E., Y. Kosako, I. Yano, H. Hotta, and Y. Nishiuchi. 1995. Transfer of two Burkholderia and an alcaligenes species to Ralstonia gen. nov. proposal of $R$. pickettii. Microbiology and Immunology. 39(11): $897-904$.
Winarno. 1997. Tantangan dan Peluang Pengembangan Jahe Menghadapi Era Pasar Bebas. Prosiding Forum Konsultasi Ilmiah Perbenihan Tanaman Rempah dan Obat. Bogor, 13 - 14 Maret 1997. Hlm.: 1-7. 
Tabel 1. Masa inkubasi bakteri $R$. solanacearum pada bibit jahe setelah perlakuan bibit

\begin{tabular}{lc}
\hline Perlakuan & Masa inkubasi (hari ) \\
\hline Konsentrasi: & \\
0 g/l & $13,8 \mathrm{c}$ \\
$2 \mathrm{~g} / \mathrm{l}$ & $35,3 \mathrm{~b}$ \\
$4 \mathrm{~g} / \mathrm{l}$ & $41,6 \mathrm{~b}$ \\
$6 \mathrm{~g} / \mathrm{l}$ & $49,3 \mathrm{a}$ \\
\hline Nilai F & $50,90^{* *}$ \\
\hline Nilai P & 0,0001 \\
\hline Lama perendaman: & \\
2 jam & 32,6 \\
5 jam & 35,3 \\
8 jam & 37,2 \\
\hline Nilai F & 1,54 \\
\hline Nilai P & 0,2341 \\
\hline
\end{tabular}

Keterangan:

Nilai tengah yang diikuti dengan huruf yang sama dalam satu kolom menyatakan tidak berbeda nyata pada uji jarak berganda Duncan $(\alpha=5 \%)$.

Tabel 2. Intensitas penyakit layu bakteri (\%) pada tanaman jahe setelah perlakuan bibit

\begin{tabular}{|c|c|c|c|c|c|}
\hline \multirow{2}{*}{ Perlakuan } & \multicolumn{5}{|c|}{ Intensitas penyakit layu bakteri (\%) pada - } \\
\hline & $4 \mathrm{msi}$ & $6 \mathrm{msi}$ & & $8 \mathrm{msi}$ & $10 \mathrm{msi}$ \\
\hline \multicolumn{6}{|l|}{ Konsentrasi: } \\
\hline $0 \mathrm{~g} / \mathrm{l}$ & 46.66 & 66.67 & $\mathrm{a}$ & 75.56 & 100.00 \\
\hline $2 \mathrm{~g} / \mathrm{l}$ & 0.00 & 20.00 & $\mathrm{~b}$ & 44.44 & 75.56 \\
\hline $4 \mathrm{~g} / \mathrm{l}$ & 2.22 & 4.44 & $\mathrm{C}$ & 28.89 & 55.56 \\
\hline $6 \mathrm{~g} / \mathrm{l}$ & 0.00 & 4.44 & c & 22.22 & 44.44 \\
\hline
\end{tabular}

\begin{tabular}{lcccc}
\hline Nilai F & $107.00^{* *}$ & $70.23^{* *}$ & $41.55^{* *}$ & $32.18^{* *}$ \\
\hline Nilai P & 0.0001 & 0.0001 & 0.0001 & 0.0001 \\
\hline Lama & & & & \\
perendaman: & & & & \\
$\quad$ jam & 15.00 & 25.00 & 45.00 & 68.33 \\
5 jam & 13.33 & 25.00 & 41.67 & 68.33 \\
$\quad 8$ jam & 8.33 & 21.67 & 41.67 & 70.00 \\
\hline Nilai F & 3.25 & 0.40 & 0.36 & 0.07 \\
\hline Nilai P & 0.0564 & 0.6747 & 0.6989 & 0.9357 \\
\hline
\end{tabular}

Keterangan:

msi $=$ minggu setelah inokulasi.

Nilai tengah yang diikuti dengan huruf yang sama dalam satu kolom menyatakan tidak berbeda nyata pada uji jarak berganda Duncan $(\alpha=5 \%)$. 